\title{
Large-scale distribution of viruses in deep waters of the Pacific and Southern Oceans
}

\author{
Yanhui Yang ${ }^{1,2}$, Taichi Yokokawa ${ }^{2,3}$, Chiaki Motegi $^{1,2,4}$, Toshi Nagata $^{1,2, *}$ \\ ${ }^{1}$ Atmosphere and Ocean Research Institute, The University of Tokyo, 5-1-5 Kashiwanoha, Kashiwa 277-8564, Japan \\ ${ }^{2}$ Center for Ecological Research, Kyoto University, Otsu, Shiga, 520-2113, Japan \\ ${ }^{3}$ Center for Marine Environmental Studies (CMES), Ehime University, Matsuyama, Ehime, 790-8577, Japan \\ ${ }^{4}$ Present address: Takuvik Joint International Laboratory, Université Laval (Canada) - CNRS (France), \\ Département de Biologie and Québec-Océan, Université Laval, Quebec G1V 0A6, Canada
}

\begin{abstract}
We examined the full-depth distributions of viruses at 38 stations along a cruise track of $\sim 17000 \mathrm{~km}$ in the Southern Ocean and the central Pacific. In the layer between 200 and $2000 \mathrm{~m}$, viral abundance decreased sharply with depth, and prokaryote abundance accounted for a large fraction $(60 \%)$ of the variability in viral abundance. In contrast, in the deeper layer (>2000 m), the depthdependent decrease in viral abundance was less evident, and the relationship between viral and prokaryote abundances was weak. Viral abundances were high in the Antarctic bottom water and tended to decrease along the paths of the Circumpolar Deep Water and the Pacific Deep Water. Outstanding peaks of virus-to-prokaryote abundance ratios (mean \pm SE: $46 \pm 1.2$ ) were found in the bottom waters (depth $>3500 \mathrm{~m}$ ) of the subtropical regions, where sinking particle fluxes are known to be generally low. These results are interpreted as an indication that large-scale viral distribution patterns are generally, if not solely, influenced by transport mediated by the meridional overturning circulation, underscoring the necessity of future studies to clarify prevailing mode and mechanisms for viral production and decay in deep oceans, which appear to be largely distinct from those in upper oceans.
\end{abstract}

KEY WORDS: Viruses - Deep ocean · Virus-toprokaryote abundance ratio - Meridional overturning circulation

\footnotetext{
*Corresponding author: nagata@aori.u-tokyo.ac.jp
}

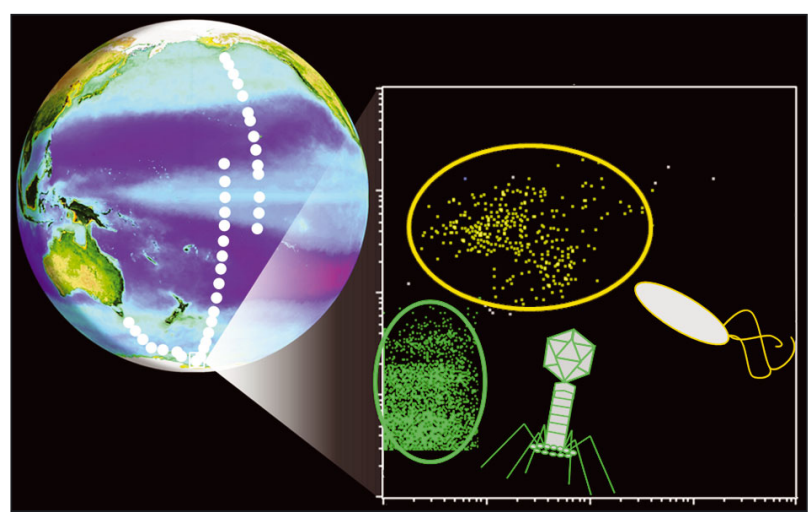

Left: Sampling stations (satellite image from NASA). Right: Dot plots of viruses (green) and prokaryotes (orange) on flow cytogram.

Illustration: C. Motegi

\section{INTRODUCTION}

Despite increasing recognition that viruses are ubiquitous and play important roles in the regulation of biogeochemical cycling and microbial community dynamics in marine environments (Suttle 2007, Danovaro et al. 2011, Breitbart 2012), our knowledge of viral distributions, variation in viral production, and the extent of viral-induced mortality of prokaryotes in deep oceanic environments is severely limited (Arístegui et al. 2009, Nagata et al. 2010, De Corte et al. 2012). This paucity of data hampers understanding of the biogeochemical cycle controls in the ocean's interior. There, large quantities of carbon

() The authors 2014. Open Access under Creative Commons by Attribution Licence. Use, distribution and reproduction are unrestricted. Authors and original publication must be credited. 
and nutrients are remineralized and sequestered, which affects the variability of atmospheric $p \mathrm{CO}_{2}$ and hence the climate of our planet (Sarmiento \& Gruber 2006, Kwon et al. 2009).

A few studies have examined viral abundance distributions throughout whole water columns of the ocean in regions of depth greater than $1000 \mathrm{~m}$ (reviewed by Arístegui et al. 2009, Nagata et al. 2010, see also De Corte et al. 2010, 2012). One astonishing feature has emerged from the compilation of available data: viruses can be much more abundant in deep waters than would be expected from the prokaryotic abundance there. Viral abundances in bathypelagic waters are reported to range from $0.6 \times 10^{8}$ to $60 \times$ $10^{8}$ viruses $l^{-1}$. These values are, in general, about $1 / 2$ to $1 / 50$ of those in the upper oceans (reviewed by Nagata et al. 2010, see also De Corte et al. 2012). Depending on the ocean region, the depth-dependent decrease in viral abundance is much less pronounced than that in prokaryote abundance, leading to higher virus-to-prokaryote abundance ratios (VPRs) in deep waters (50 to 110 in the bathypelagic layer of the North Atlantic; Parada et al. 2007, De Corte et al. $2010,2012)$ than those commonly reported in previous studies ( 10, Wommack \& Colwell 2000). High VPRs in deep oceans are intriguing, given that the extremely low growth rates of prokaryotes in deep waters $\left(10^{-4}\right.$ to $10^{-2} \mathrm{~d}^{-1}$ in the bathypelagic; Arístegui et al. 2009, Yokokawa et al. 2013) should severely limit lytic viral production.

Because viral populations are affected by both viral production and decay, the high viral abundance and VPR could be explained by a relatively low decay rate of viruses in deep waters (De Corte et al. 2010). Parada et al. (2007) reported viral turnover time in deep Atlantic waters to be around 11 to $39 \mathrm{~d}$, which was $\sim 10$-fold longer than that for viruses in surface waters (Parada et al. 2007, De Corte et al. 2012). An alternative, if not mutually exclusive, hypothesis is that the high VPR at depth is a consequence of viral delivery to deep waters from upper layers. Some authors have suggested that the high VPR and apparent lack of a relation between viral and prokaryotic abundance in deep Atlantic waters might be caused by the allochthonous input of viruses attached to sinking particles from surface waters (Parada et al. 2007, De Corte et al. 2012). Viral transport due to vertical mixing and lateral advection might also affect viral abundance distribution patterns in deep oceanic waters (Nagata et al. 2010). However, the mechanisms underlying viral abundance distribution patterns in deep oceanic waters are not entirely clear.
Examination of viral distributions across different large-scale oceanic regions may provide clues to the factors that affect viral abundances and the VPR in the ocean interior. We collected data on full-depth distributions of viruses along a cruise track of $\sim 17000 \mathrm{~km}$ in the Southern Ocean and the central Pacific. The sampled stations represented diverse biogeochemical provinces (polar, subpolar, subtropi$\mathrm{cal}$, and equatorial) with different prokaryote abundances and production (Yokokawa et al. 2013) and covered a full physical dimension of the meridional overturning circulation in the central Pacific and Southern Oceans.

\section{MATERIALS AND METHODS}

\section{Study sites}

We sampled 38 stations in the central Pacific and the Pacific sector of the Southern Ocean along 4 transects covering a latitudinal range of $67^{\circ} \mathrm{S}$ to $53.6^{\circ} \mathrm{N}$, during 2 cruises aboard the RV 'Hakuho-

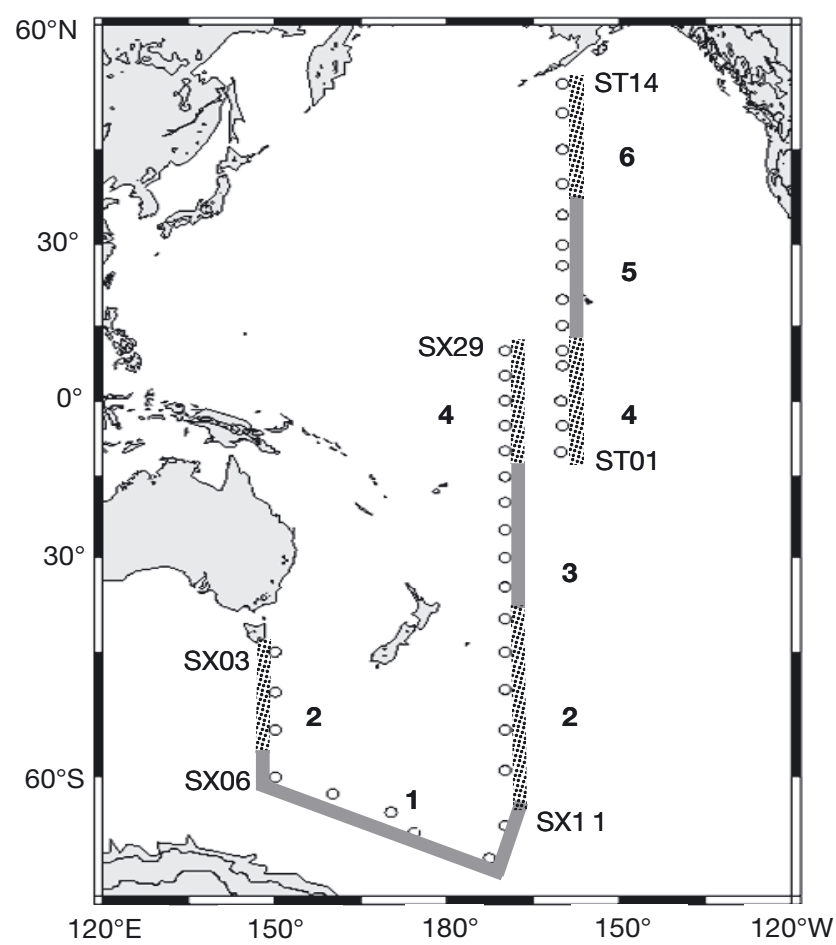

Fig. 1. Sampling stations deployed during the KH04-5 (SX03-SX29) and KH05-2 (ST01-ST14) cruises. Station codes are presented for selected stations only, for clarity. Regional numbers are added to separate the Antarctic region (1), the subantarctic/subtropical convergence zone (2), the South Pacific subtropical region (3), the equatorial region (4), the North Pacific subtropical region (5), and the subarctic/North Pacific transition zone (6) 
maru' (cruise KH04-5, Stns SX03-SX29, December 2004 to March 2005; and cruise KH05-2, Stns ST01-ST14, August to September 2005; Fig. 1). The sampling sites were located in various biogeochemical provinces (Longhurst 2006), including the Antarctic (Region 1), the subantarctic and subtropical convergence zone (Region 2), the South Pacific subtropical zone (Region 3), the equator (Region 4), the North Pacific subtropical zone (Region 5), and the subarctic and North Pacific transition zone (Region 6). The major water masses in deep waters included the Circumpolar Deep Water (CDW; potential density $\sigma_{\theta}>27.79$ ) and the Pacific Deep Water (PDW; $\sigma_{\theta} \sim 27.51$ to 27.79; Schmitz 1996; see Fig. 2A). CDW contains the modified North Atlantic Deep Water, which is replenished by newly formed deep water from the Antarctic shelf-slope region. A portion of the CDW flows northward along the Western Boundary Currents and forms the bottom water in the Pacific Ocean. During the transit, the CDW gains buoyancy through mixing with the overlaying waters and then returns south as PDW, until it is entrained with the surface water in the Antarctic zone. The mid-water PDW in the North Pacific is the oldest water mass, as indicated by ocean ${ }^{14} \mathrm{C}$ data (Matsumoto 2007).

\section{Determination of oceanographic parameters and viral abundance}

At each station, water samples were collected at 7 to 8 different depths (50 to $200 \mathrm{~m}$ depth interval) in the water column between 200 and $1000 \mathrm{~m}$, and at every 250 to $500 \mathrm{~m}$ depth interval in the deeper water to the bottom layer (50 or $100 \mathrm{~m}$ above the sea floor), using clean 121 Niskin-X bottles (General Oceanics) attached to a carousel water sampler equipped with a conductivity-temperature-depth profiler (Sea-Bird Electronics, Model 9 plus); these were used to determine viral abundance, prokaryote abundance, and production and other oceanographic parameters (salinity, apparent oxygen utilization [AOU], chlorophyll a concentrations, concentrations of nitrate, nitrite, phosphate, and silicate). Data on prokaryote variables, except for samples from Stns SX03 to SX09 in Regions 1 and 2, have been reported by Yokokawa et al. (2013). The data for prokaryote variables and oceanographic parameters used in this study are available online via the Full Depth Distribution of Microbial Abundance and Production Database (FddMAP, http://cesd.aori.u-tokyo.ac.jp/ cesddb/index_en.html).
Details on the method used to analyze viral abundance have been described elsewhere (Yang et al. 2010). Briefly, seawater samples were stored in $5 \mathrm{ml}$ cryovials (Nalgene) fixed with $0.02 \mu \mathrm{m}$ filtered glutaraldehyde (final concentration $1 \%$ ) and flash frozen in liquid nitrogen during KH05-2. Because of logistic constraints, liquid nitrogen was not available on board during KH04-5, and the samples were directly frozen in a deep freezer $\left(-80^{\circ} \mathrm{C}\right)$ (see 'Discussion'). Samples were then stored in a deep freezer $\left(-80^{\circ} \mathrm{C}\right)$ until analysis. In the onshore laboratory, the samples were thawed, diluted (20 to $100 \times$ ) with TE buffer $\left(10 \mathrm{mmol} \mathrm{l}^{-1}\right.$ Tris-HCl, $1 \mathrm{mmol} \mathrm{l^{-1 }}$ ethylenediamine tetraacetic acid, $\mathrm{pH}$ 8.0; Wako), stained with SYBR Green I (final concentration $5 \times 10^{-5}$, at $80^{\circ} \mathrm{C}$ for $10 \mathrm{~min}$ ), and injected into a flow cytometer (FACSCalibur, Becton Dickinson) with standard beads (1 $\mu$ m yellow-green beads, Molecular Probes). Triplicate blanks were run every 8 to 10 samples. The blank values were $<5 \%$ of the total count. The variation in flow rate was 2 to $3 \%$. The obtained data were analyzed using the CellQuest software (Becton Dickinson).

\section{Statistical analysis}

Linear regression was conducted using SigmaStat 3.1 (Hulinks) to analyze the relationships between viral abundance and other variables. A distancebased linear model (DistLM) using distance-based redundancy analysis (dbRDA) in Primer v6 (PRIMERE) was used to select the best set of environmental (potential temperature, salinity, $\sigma_{\theta}$ AOU, nutrients [concentrations of nitrate, phosphate, and silicate]), geographic (latitude and depth), and prokaryotic variables (abundance, production, and cell-specific production) to account for the variability in viral abundance. Viral abundance and prokaryotic variables were log transformed for the analysis. The model was based on a stepwise procedure and the Bayesian information criterion (Anderson et al. 2008).

\section{RESULTS}

\section{Viral abundance distribution patterns in the upper water layer (200 to $2000 \mathrm{~m}$ )}

Vertically, the viral abundance decreased sharply in the upper layer (200 to $2000 \mathrm{~m}$ ). Linear regressions of $\log$ (viral abundance) versus log (depth) were generally significant $(p<0.05)$, with exponents in the 

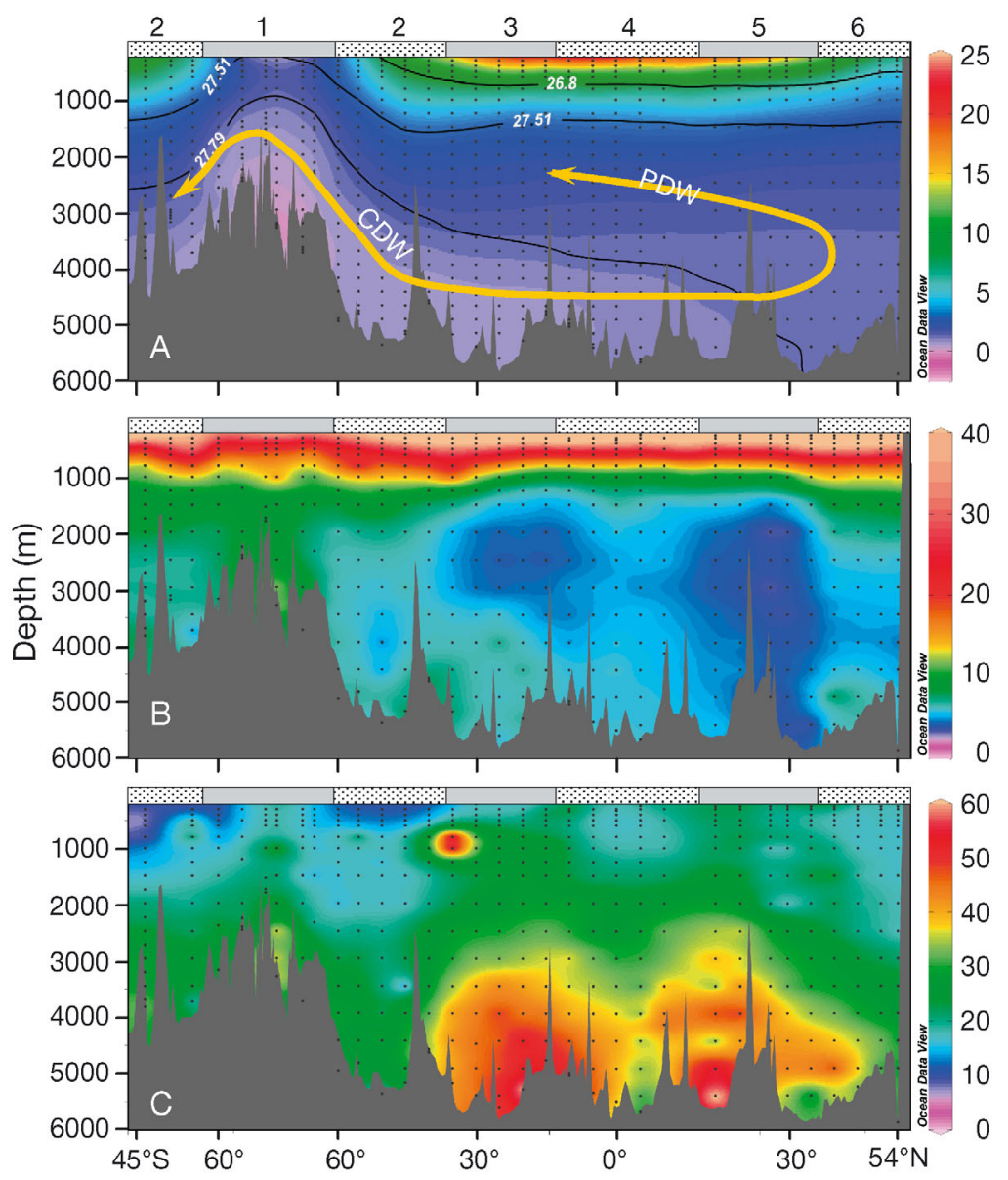

Fig. 2. (A) Water potential temperature $\left({ }^{\circ} \mathrm{C}\right.$, color scale) and $\sigma_{\theta}\left(\mathrm{kg} \mathrm{m}^{-3}\right.$, contour lines) showing also the direction of the Circumpolar Deep Water (CDW) and Pacific Deep Water (PDW) circulation. Isopycnal lines separate the different water masses according to Schmitz (1996). (B) Distributions of viral abundance $\left(10^{8}\right.$ particles $\left.\mathrm{l}^{-1}\right)$. (C) Virus-to-prokaryote abundance ratios along the cruise tracks. The $x$-axis is scaled by the distance from Stn SX03 along the cruise tracks, although ticks and labels are added to indicate latitudinal positions. To create the contour, data collected at Stns ST01-ST05 were not used, to avoid overlapping of data collected during the KH04-5 and KH05-2 cruises for the same latitude (see Fig. 1). The bars and numbers on the top $x$-axis correspond to the regional numbers presented in Fig. 1. The dots in the graphs indicate water sampling layers. The gray area shows the sea floor topography; created using Ocean Data View (http://odv.awi.de/)

range of -1.21 to -0.37 (Table 1). Regressions were non-significant $(p>0.05)$ or weak (slope $>-0.5)$ at 6 stations in the Antarctic or subantarctic regions (SX03, 06 to 10). The VPR was on average $19 \pm 0.6$ $\left(\mathrm{SE}_{;} \mathrm{n}=355\right)$. The DistLM analysis selected prokaryotic abundance and $\sigma_{\theta}$ as the factors best explaining the variability in viral abundance $\left(\mathrm{R}^{2}=0.648\right)$. Among the predictor variables, prokaryotic abundance alone explained much $(60 \%)$ of the variability in viral abundance (Table 2).

\section{Viral abundance distribution patterns in the deeper water layer $(>2000 \mathrm{~m})$}

In contrast to the vertical patterns in the upper layer, the decrease in viral abundance with depth was either nonsignificant $(p>0.05)$ or less evident (slope $>-0.5$ ) at most (37 out of 38) of the stations (Table 3) in the deeper layer $>2000 \mathrm{~m}$. At 9 stations, viral abundance displayed an increasing trend with depth (Fig. 2B, Table 3). The average VPR for the whole data collected in the layer deeper than $2000 \mathrm{~m}$ was $34 \pm 0.8$ (SE, $\mathrm{n}=206$ ). Peaks of VPR (up to 70) were found in the near bottom waters (depth $>3500 \mathrm{~m}$ ) in the subtropical regions of the South and North Pacific, where the average VPR was $46 \pm 1.2(\mathrm{n}=$ 36; Regions 3 and 5; Fig. 2C).

Viral abundance displayed an outstanding, large-scale, latitudinal pattern. Viral abundance was highest in the bottom water of the Antarctic (Region 1), where it reached $13 \times 10^{8}$ particles $l^{-1}$ $\left(174^{\circ} \mathrm{E}, 65^{\circ} \mathrm{S}, 3000 \mathrm{~m}\right.$ to the bottom; Fig. 2B). Then it gradually decreased during the northward transit of the CDW, followed by the return southward with the PDW in the mid-water column. Viral abundance was low in the PDW, with the lowest value found at depths of 2000 to $3000 \mathrm{~m}$ in the subtropical North Pacific (Region 5). The subarctic North Pacific was an exception (Region 6), with a relatively high viral abundance in the near bottom layer (Fig. 2B).

We found significant $\left(\mathrm{R}^{2}=0.15\right.$ to 0.24 , $\mathrm{p}<0.001)$ relationships between viral abundance and the physical and chemical variables $\left(\sigma_{\theta}\right.$, potential temperature, salinity, AOU, nitrate, phosphate, and silicate) that generally display a strong gradient along the paths of the CDW and PDW, reflecting the age of water masses (Sarmiento \& Gruber 2006; Table 4). The highest $\mathrm{R}^{2}$ value was found for the relationship between viral abundance and $\sigma_{\theta}$. The high viral abundance in the subarctic (Region 6) deviated from the general decreasing trend along the paths of the CDW and PDW. Therefore, we performed a regression analysis excluding the data from Region 6. With this re-analysis, the regression was largely improved for all predictor variables, with $\sigma_{\theta}$ 
Table 1. Regression results of changes in viral abundance for the upper water layer (200-2000 m). The model is $N=N_{200}$ $(Z / 200)^{b}$, where $N$ is viral abundance $\left(10^{8}\right.$ particles $\left.l^{-1}\right), Z$ is depth $(\mathrm{m}), N_{200}$ is viral abundance $\left(10^{8}\right.$ particles $\left.l^{-1}\right)$ at a depth of $200 \mathrm{~m}$, and $b$ is the exponent. Statistical parameters were estimated by the linear regression of $\log N$ over $\log (Z / 200)$.

'-': regression was non-significant $(\mathrm{p}>0.05)$

\begin{tabular}{|c|c|c|c|c|c|c|c|c|c|}
\hline Cruise & Latitude & Longitude & Station & Max depth (m) & $N_{200}$ & $b \pm \mathrm{SE}$ & $\mathrm{n}$ & $\mathrm{R}^{2}$ & $\mathrm{p}$ \\
\hline \multirow{24}{*}{ KH04-5 } & $44.9^{\circ} \mathrm{S}$ & $149.9^{\circ} \mathrm{E}$ & SX03 & 3591 & - & - & - & - & - \\
\hline & $50.3^{\circ} \mathrm{S}$ & $150.0^{\circ} \mathrm{E}$ & SX04 & 3166 & 36.3 & $-0.65 \pm 0.05$ & 11 & 0.91 & $<0.001$ \\
\hline & $55.0^{\circ} \mathrm{S}$ & $150.0^{\circ} \mathrm{E}$ & SX05 & 3704 & 80.0 & $-1.05 \pm 0.20$ & 11 & 0.78 & $<0.001$ \\
\hline & $60.0^{\circ} \mathrm{S}$ & $150.0^{\circ} \mathrm{E}$ & SX06 & 3270 & - & - & - & - & - \\
\hline & $61.7^{\circ} \mathrm{S}$ & $160.0^{\circ} \mathrm{E}$ & SX07 & 2395 & 17.9 & $-0.37 \pm 0.01$ & 5 & 0.88 & 0.017 \\
\hline & $63.4^{\circ} \mathrm{S}$ & $170.1^{\circ} \mathrm{E}$ & SX08 & 1813 & 23.1 & $-0.45 \pm 0.04$ & 9 & 0.96 & $<0.001$ \\
\hline & $65.1^{\circ} \mathrm{S}$ & $174.2^{\circ} \mathrm{E}$ & SX09 & 3316 & 23.0 & $-0.37 \pm 0.13$ & 8 & 0.59 & 0.026 \\
\hline & $67.2^{\circ} \mathrm{S}$ & $172.7^{\circ} \mathrm{W}$ & SX10 & 3741 & 15.9 & $-0.37 \pm 0.05$ & 9 & 0.89 & $<0.001$ \\
\hline & $64.5^{\circ} \mathrm{S}$ & $170.0^{\circ} \mathrm{W}$ & SX11 & 2369 & 17.2 & $-0.58 \pm 0.15$ & 7 & 0.71 & 0.017 \\
\hline & $59.4^{\circ} \mathrm{S}$ & $170.0^{\circ} \mathrm{W}$ & SX12 & 4941 & 33.1 & $-0.73 \pm 0.12$ & 10 & 0.81 & $<0.001$ \\
\hline & $55.0^{\circ} \mathrm{S}$ & $170.0^{\circ} \mathrm{W}$ & SX13 & 4844 & 28.6 & $-0.51 \pm 0.18$ & 9 & 0.54 & 0.023 \\
\hline & $50.0^{\circ} \mathrm{S}$ & $170.0^{\circ} \mathrm{W}$ & SX14 & 5347 & 27.5 & $-0.57 \pm 0.04$ & 10 & 0.96 & $<0.001$ \\
\hline & $45.0^{\circ} \mathrm{S}$ & $170.0^{\circ} \mathrm{W}$ & SX15 & 5165 & 34.1 & $-0.73 \pm 0.08$ & 9 & 0.92 & $<0.001$ \\
\hline & $40.0^{\circ} \mathrm{S}$ & $170.0^{\circ} \mathrm{W}$ & SX17 & 4635 & 37.4 & $-0.82 \pm 0.05$ & 10 & 0.97 & $<0.001$ \\
\hline & $35.0^{\circ} \mathrm{S}$ & $170.0^{\circ} \mathrm{W}$ & SX19 & 5170 & 39.9 & $-0.77 \pm 0.22$ & 10 & 0.61 & 0.008 \\
\hline & $30.0^{\circ} \mathrm{S}$ & $170.0^{\circ} \mathrm{W}$ & SX20 & 5338 & 27.5 & $-0.78 \pm 0.09$ & 10 & 0.90 & $<0.001$ \\
\hline & $25.0^{\circ} \mathrm{S}$ & $170.0^{\circ} \mathrm{W}$ & SX21 & 5608 & 36.1 & $-0.99 \pm 0.09$ & 10 & 0.93 & $<0.001$ \\
\hline & $20.0^{\circ} \mathrm{S}$ & $170.0^{\circ} \mathrm{W}$ & SX22 & 5252 & 28.6 & $-0.86 \pm 0.07$ & 10 & 0.94 & $<0.001$ \\
\hline & $15.0^{\circ} \mathrm{S}$ & $170.0^{\circ} \mathrm{W}$ & SX24 & 4750 & 26.5 & $-0.93 \pm 0.04$ & 10 & 0.99 & $<0.001$ \\
\hline & $10.0^{\circ} \mathrm{S}$ & $170.0^{\circ} \mathrm{W}$ & SX25 & 4999 & 38.9 & $-1.10 \pm 0.08$ & 10 & 0.96 & $<0.001$ \\
\hline & $4.9^{\circ} \mathrm{S}$ & $170.0^{\circ} \mathrm{W}$ & SX26 & 5329 & 31.8 & $-0.89 \pm 0.08$ & 10 & 0.94 & $<0.001$ \\
\hline & $0.1^{\circ} \mathrm{N}$ & $170.0^{\circ} \mathrm{W}$ & SX27 & 5423 & 31.5 & $-0.77 \pm 0.05$ & 10 & 0.96 & $<0.001$ \\
\hline & $5.1^{\circ} \mathrm{N}$ & $170.0^{\circ} \mathrm{W}$ & SX28 & 5616 & 27.0 & $-0.80 \pm 0.06$ & 10 & 0.96 & $<0.001$ \\
\hline & $10.2^{\circ} \mathrm{N}$ & $170.0^{\circ} \mathrm{W}$ & SX29 & 4329 & 27.1 & $-0.87 \pm 0.13$ & 8 & 0.87 & $<0.001$ \\
\hline \multirow[t]{14}{*}{ KH05-2 } & $10.0^{\circ} \mathrm{S}$ & $160.3^{\circ} \mathrm{W}$ & ST01 & 5078 & 31.9 & $-1.08 \pm 0.12$ & 10 & 0.91 & $<0.001$ \\
\hline & $5.0^{\circ} \mathrm{S}$ & $160.0^{\circ} \mathrm{W}$ & ST02 & 5313 & 25.0 & $-0.79 \pm 0.18$ & 10 & 0.70 & 0.003 \\
\hline & $0^{\circ}$ & $160.0^{\circ} \mathrm{W}$ & ST03 & 5053 & 27.8 & $-0.70 \pm 0.04$ & 10 & 0.98 & $<0.001$ \\
\hline & $7.2^{\circ} \mathrm{N}$ & $160.0^{\circ} \mathrm{W}$ & ST04 & 4160 & 36.8 & $-0.84 \pm 0.05$ & 10 & 0.98 & $<0.001$ \\
\hline & $10.1^{\circ} \mathrm{N}$ & $160.0^{\circ} \mathrm{W}$ & ST05 & 5165 & 31.1 & $-0.83 \pm 0.05$ & 10 & 0.97 & $<0.001$ \\
\hline & $15.0^{\circ} \mathrm{N}$ & $160.0^{\circ} \mathrm{W}$ & ST06 & 5477 & 34.0 & $-0.99 \pm 0.09$ & 10 & 0.94 & $<0.001$ \\
\hline & $20.0^{\circ} \mathrm{N}$ & $160.0^{\circ} \mathrm{W}$ & ST07 & 4513 & 40.4 & $-0.99 \pm 0.06$ & 10 & 0.97 & $<0.001$ \\
\hline & $26.3^{\circ} \mathrm{N}$ & $160.0^{\circ} \mathrm{W}$ & ST08 & 5156 & 21.7 & $-1.07 \pm 0.17$ & 10 & 0.83 & $<0.001$ \\
\hline & $30.0^{\circ} \mathrm{N}$ & $160.0^{\circ} \mathrm{W}$ & ST09 & 5744 & 35.5 & $-1.21 \pm 0.17$ & 10 & 0.87 & $<0.001$ \\
\hline & $35.0^{\circ} \mathrm{N}$ & $160.0^{\circ} \mathrm{W}$ & ST10 & 5731 & 40.6 & $-0.91 \pm 0.11$ & 10 & 0.90 & $<0.001$ \\
\hline & $40.0^{\circ} \mathrm{N}$ & $160.0^{\circ} \mathrm{W}$ & ST11 & 5475 & 44.1 & $-0.78 \pm 0.23$ & 10 & 0.60 & 0.009 \\
\hline & $45.0^{\circ} \mathrm{N}$ & $160.0^{\circ} \mathrm{W}$ & ST12 & 5279 & 23.7 & $-0.59 \pm 0.12$ & 10 & 0.76 & $<0.001$ \\
\hline & $50.0^{\circ} \mathrm{N}$ & $160.0^{\circ} \mathrm{W}$ & ST13 & 4952 & 38.9 & $-0.75 \pm 0.04$ & 10 & 0.97 & $<0.001$ \\
\hline & $53.6^{\circ} \mathrm{N}$ & $160.0^{\circ} \mathrm{W}$ & ST14 & 6423 & 30.2 & $-0.66 \pm 0.06$ & 10 & 0.94 & $<0.001$ \\
\hline
\end{tabular}

accounting for $37 \%$ of the variability in viral abundance (Table 4, Fig. 3). The results of the DistLM analysis indicated that the best set of variables to account for the viral abundance variability was a combination of $\sigma_{\theta}$ and prokaryote abundance (Table 2). The $\sigma_{\theta}$ and prokaryote abundance accounted for 15

Fig. 3. Relationship between viral abundance $\left(10^{8}\right.$ particles $\mathrm{l}^{-1}$ ) and $\sigma_{\theta}$ in the Circumpolar Deep Water (CDW) and the Pacific Deep Water (PDW) of the deeper (>2000 m) layer (data collected in Region 6 were not used; see 'Results'), showing the gradual decrease in viral abundance along the transport of CDW and PDW. The solid lines show the linear regression with a $95 \%$ confidence interval, and the dashed lines show the $95 \%$ prediction interval. The regression equation was as follows $( \pm \mathrm{SE})$ : $\log$ viral abundance $\left(10^{8}\right.$ particles $\left.\mathrm{l}^{-1}\right)=-51.7$ $( \pm 5.2)+1.89( \pm 0.19) \times \sigma_{\theta}\left(R^{2}=0.37, \mathrm{p}<0.001, \mathrm{n}=175\right)$

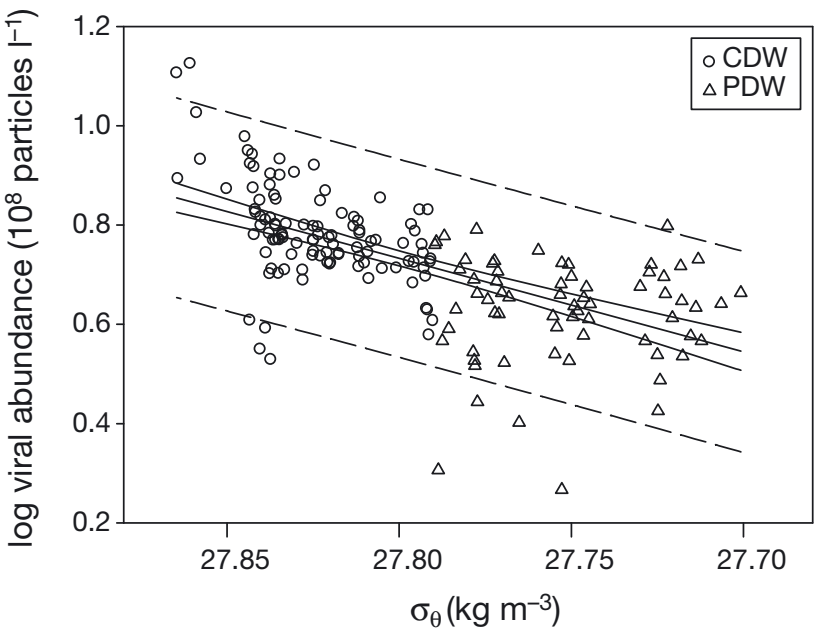


Table 2. Distance-based linear model results of environmental variables that account for the variability in viral abundance. The analyses were conducted for the samples collected in the upper layer $(200-2000 \mathrm{~m}, \mathrm{n}=336)$, for those collected in the deeper layer $(>2000 \mathrm{~m}, \mathrm{n}=202$ ), and for the subset of the deeper layer samples excluding those from Region 6 ( $\mathrm{n}=168$ ). Pseudo- $F$ and p-values were obtained by permutations (number of permutations $=999$ ). Coefficient is for a linear combination of predictor variables in the formation of the distance-based redundancy analysis coordinate (Axis 1). AOU: apparent oxygen utilization. Bold: sum of $\mathrm{R}^{2}$

\begin{tabular}{|c|c|c|c|c|c|}
\hline Response variable & Selection & Pseudo- $F$ & $\mathrm{p}$ & $\mathrm{R}^{2}$ & Coefficient \\
\hline Viral abundance (200-2000 m) & $\begin{array}{l}\text { Prokaryotic abundance } \\
\sigma_{\theta}\end{array}$ & $\begin{array}{r}493.77 \\
48.17\end{array}$ & $\begin{array}{l}0.001 \\
0.001\end{array}$ & $\begin{array}{l}0.597 \\
0.051 \\
\mathbf{0 . 6 4 8}\end{array}$ & $\begin{array}{r}0.580 \\
-0.151\end{array}$ \\
\hline Viral abundance (>2000 m; All) & $\begin{array}{l}\text { Prokaryotic abundance } \\
\sigma_{\theta}\end{array}$ & $\begin{array}{l}94.73 \\
54.44\end{array}$ & $\begin{array}{l}0.001 \\
0.001\end{array}$ & $\begin{array}{l}0.321 \\
0.146 \\
\mathbf{0 . 4 6 7}\end{array}$ & $\begin{array}{l}-0.352 \\
-1.260\end{array}$ \\
\hline Viral abundance (>2000 m; Region 6 excluded) & $\begin{array}{l}\text { AOU } \\
\text { Prokaryotic abundance } \\
\text { Silicate } \\
\text { Potential temperature } \\
\text { Phosphate }\end{array}$ & $\begin{array}{r}131.08 \\
38.10 \\
20.40 \\
10.34 \\
7.87\end{array}$ & $\begin{array}{l}0.001 \\
0.001 \\
0.001 \\
0.003 \\
0.008\end{array}$ & $\begin{array}{l}0.441 \\
0.105 \\
0.048 \\
0.027 \\
0.018 \\
\mathbf{0 . 6 3 9}\end{array}$ & $\begin{array}{r}0.007 \\
0.178 \\
-0.005 \\
-0.269 \\
-0.511\end{array}$ \\
\hline
\end{tabular}

Table 3. Regression results of changes in viral abundance for the deeper water layer ( $>2000 \mathrm{~m}$, see Table 1 for the maximum depth of each station). The model is $N=N_{2000}(\mathrm{Z} / 2000)^{b}$, where $N$ is viral abundance $\left(10^{8}\right.$ particles $\left.l^{-1}\right), Z$ is depth (m), $N_{2000}$ is viral abundance $\left(10^{8}\right.$ particles $\left.\mathrm{l}^{-1}\right)$ at a depth of $2000 \mathrm{~m}$, and $b$ is the exponent. Statistical parameters were estimated by the linear regression of $\log N$ over $\log (Z / 2000)$. The regression was non-significant ( $p>0.05)$ at stations not shown in this table

\begin{tabular}{|lcrrrrr|}
\hline Cruise & Station & $N_{2000}$ & \multicolumn{1}{c}{$b \pm \mathrm{SE}$} & $\mathrm{n}$ & $\mathrm{R}^{2}$ & $\mathrm{p}$ \\
\hline KH04-5 & SX12 & 5.1 & $0.26 \pm 0.07$ & 7 & 0.73 & 0.014 \\
& SX14 & 6.9 & $-0.72 \pm 0.17$ & 7 & 0.79 & 0.007 \\
& SX19 & 4.4 & $0.56 \pm 0.11$ & 8 & 0.82 & 0.002 \\
& SX20 & 4.0 & $0.44 \pm 0.07$ & 8 & 0.85 & 0.001 \\
& SX22 & 4.2 & $0.55 \pm 0.16$ & 8 & 0.67 & 0.013 \\
& SX24 & 3.1 & $0.76 \pm 0.10$ & 7 & 0.92 & $<0.001$ \\
& SX26 & 4.7 & $0.76 \pm 0.05$ & 8 & 0.59 & 0.025 \\
KH05-2 & ST02 & 4.0 & $0.41 \pm 0.09$ & 8 & 0.77 & 0.004 \\
& ST06 & 3.7 & $0.33 \pm 0.07$ & 8 & 0.77 & 0.004 \\
& ST09 & 2.1 & $0.71 \pm 0.26$ & 8 & 0.55 & 0.035 \\
& ST14 & 6.0 & $-0.31 \pm 0.13$ & 8 & 0.50 & 0.05 \\
\hline
\end{tabular}

and $32 \%$ of the variability in viral abundance, respectively. For the subset of data excluding Region 6 , AOU $\left(R^{2}=0.44\right)$ was selected as the strongest predictor variable explaining variability in viral abundance (Table 2).

\section{DISCUSSION}

Our extensive data collected in the Pacific and Southern Oceans provided a unique opportunity to infer possible factors affecting viral distributions in deep waters across basins. Below, we first discuss how host-virus interactions and viral transport might influence viral distributions. We then discuss intrigu- ing features in viral turnover times and the potential roles of viruses in biogeochemical cycles in the ocean's interior.

\section{Virus-host interactions}

In the upper ocean, previous studies have demonstrated that a significant fraction (20 to $40 \%$ ) of the prokaryote biomass is lysed by viruses (Suttle 2005) and that there are broad positive correlations between viral abundance and host abundance and productivity (Yang et al. 2010, Danovaro et al. 2011). Such data have generally been interpreted as an indication that viral abundance distributions are influenced by host availability (Yang et al. 2010, Danovaro et al. 2011). In contrast, in deep oceans, data on host-virus couplings are severely limited (Arístegui et al. 2009, Nagata et al. 2010). The available data have provided 2 lines of evidence indicating that lytic viral production could occur at greater depths. First, Weinbauer et al. (2003) determined the frequency of virus-infected cells at depths of 800 to $2000 \mathrm{~m}$ in the Mediterranean. Their results suggested that at least 3 to $6 \%$ of prokaryote mortality was due to lytic viral production. Second, based on dilution or virus-reduction methods, viral-induced prokaryote mortality has been reported to be $13.6 \%$ $\mathrm{d}^{-1}$ on average in deep Mediterranean waters (Fonda Umani et al. 2010), and lytic viral production rates 
Table 4. Coefficients of determination $\left(\mathrm{R}^{2}\right)$ for the linear regression of viral abundance (log transformed) on the physical and chemical variables in the deeper layer $(>2000 \mathrm{~m}$, $\mathrm{n}=209-212$ ), or the subset excluding data from Region 6 $(n=175-177)$. Letters in parentheses indicate the sign of the regression slope ( $\mathrm{N}$ : negative, $\mathrm{P}$ : positive). $\mathrm{p}$ was $<0.001$ for all of the regressions. AOU: apparent oxygen utilization

\begin{tabular}{|lccrl|}
\hline Variables & \multicolumn{2}{c}{ All } & Region 6 excluded \\
\hline Potential temperature & 0.211 & $(\mathrm{~N})$ & 0.289 & $(\mathrm{~N})$ \\
Salinity & 0.151 & $(\mathrm{P})$ & 0.260 & $(\mathrm{P})$ \\
$\sigma_{\theta}$ & 0.239 & $(\mathrm{P})$ & 0.368 & $(\mathrm{P})$ \\
AOU & 0.223 & $(\mathrm{~N})$ & 0.434 & $(\mathrm{~N})$ \\
Nitrate & 0.238 & $(\mathrm{~N})$ & 0.386 & $(\mathrm{~N})$ \\
Silicate & 0.161 & $(\mathrm{~N})$ & 0.378 & $(\mathrm{~N})$ \\
Phosphate & 0.194 & $(\mathrm{~N})$ & 0.379 & $(\mathrm{~N})$ \\
\hline
\end{tabular}

have been reported to vary in the range of $0.04 \times$ $10^{5}-3.5 \times 10^{5}$ particles $\mathrm{ml}^{-1} \mathrm{~h}^{-1}$ in deep Atlantic waters (De Corte et al. 2010, 2012). In the present study, the DistLM analyses of the data collected in the upper layer (200 to $2000 \mathrm{~m}$ ) selected prokaryote abundance as a significant predictor variable that explains a large fraction (60\%) of the variability in viral abundance. Because depth was not selected as a significant predictor variable, the relationship between prokaryote and viral abundances would not be simply explained by the vertical gradients of these 2 variables. These results support the notion that viral abundance distributions are influenced by host (prokaryote) availability in the upper layer (200 to $2000 \mathrm{~m}$ ) of the deep oceans.

In contrast in the deeper layer (>2000 m), the relationship between viral abundance and prokaryote variables was relatively weak (Table 2), and there were major discrepancies between viral distributions and the distribution of prokaryote variables observed during the same transect cruises. Viral distributions identified in the present study differ from the prokaryote abundance and production distributions reported by Yokokawa et al. (2013) in the following 3 aspects: (1) prokaryote abundance was low in the subtropical bottom water of the South Pacific, whereas viral abundance was relatively high; (2) prokaryote production peaked in the bathypelagic layer of the subtropical North Pacific, whereas viral abundance was relatively low in the corresponding layer; and (3) prokaryote abundance decreased sharply with depth throughout the water column, whereas a depth-dependent decrease was not evident for viruses in deeper layers. These results indicate that host-dependent viral lytic production only partially explains the patterns of viral abundance distribution that we found in deeper layers.
The lack of a tight relationship between prokaryote and virus abundance does not necessarily indicate the lack of virus-host couplings in deep oceans. In deep waters, viruses may use multiple strategies to cope with extremely low host abundance and productivity. These strategies may include the prevalence of lysogeny and large burst size (Weinbauer et al. 2003, Parada et al. 2006). However, the data currently available regarding lysogeny in deep oceanic environments are conflicting: it has been reported that lysogenic infection increased with depth in the Mediterranean (Weinbauer et al. 2003), whereas other studies have failed to detect such a trend in the Atlantic Ocean (De Corte et al. 2010, 2012). Furthermore, the available burst size data are not sufficient to evaluate a general trend with depth (Weinbauer et al. 2003, Hwang \& Cho 2010). Whether or not lysogenic production and burst size help to explain the large-scale distribution of viruses that we found in this study requires further investigation.

\section{Vertical and lateral transport of viruses}

Similar to our results for the deeper layers of the Pacific and Southern Oceans, recent studies conducted in the Atlantic have found high viral abundances, high VPRs, and an apparent lack of a tight correlation between viral and prokaryotic variables in deep water (Parada et al. 2007, De Corte et al. $2010,2012)$. These have led to the hypothesis that the physical transport of viruses attached to sinking particles (which may also act as 'hot spots' of viral production) and subsequent dissociation in deeper layers (Proctor \& Fuhrman 1991, Taylor et al. 2003, Bochdansky et al. 2010) could account for high viral abundance and high VPR in deep waters, although previous studies have not found direct evidence to support this notion. According to this sinking-particle transport hypothesis, viral abundance and VPR would be expected to be high in regions where sinking particulate organic carbon (POC) fluxes are high. Such an expectation contradicts our observation in deeper layers: we found that viral abundance and VPR were relatively high in the subtropical regions where sinking POC fluxes are reported to be generally low (Honjo et al. 2008). Thus, our data do not support the hypothesis that viral distribution patterns are mainly shaped by sinking particle fluxes over a large scale, although we do not exclude the possibility that sinking particles play a crucial role in the vertical delivery of viruses in some local or regional settings. 
Viral distributions in deeper layers might be influenced by convective mixing and lateral advection (Nagata et al. 2010). To test this, we compared largescale patterns in viral abundance distributions with those of water masses. Our data provided 3 lines of evidence in support of this notion: (1) in the deeper layer, viral abundance was highest in the bottom water of the Antarctic where large quantities of viruses could be transported from the surface to the deeper layers through convective mixing (Orsi et al. 1999); (2) viral abundance gradually decreased along the paths of the CDW and PDW, consistent with the notion that water flow influenced large-scale viral distributions; and (3) viral abundances were significantly correlated to physical and chemical parameters that reflect the age of water masses, suggesting a slow depletion in viral abundance during transits across the basins. The high viral abundance in Region 6, especially in the near bottom layer, deviated from the general decreasing trend along the paths of the CDW and PDW. This might be related to high sinking particle fluxes in the subarctic Pacific (Honjo et al. 2008) and the sinking particle-mediated delivery of viruses from the upper to the deeper layers, as suggested to occur in the Atlantic basin (Parada et al. 2007, De Corte et al. 2010, 2012).

A methodological problem should be noted. In this study, the preservation (freezing) procedures of viral samples differed between the 2 cruises (KH04-5 and KH05-2). Because each cruise occupied a northern and a southern part of the latitudinal transects (Fig. 1), the differences in preservation procedures would have influenced latitudinal distribution if there were systematic and large differences in viral abundance estimates arising from the different preservation procedures (e.g. Wen et al. 2004). Although we lack data on a direct comparison of deep-water viral abundances determined using different preservation procedures, the following evidence suggests that this effect was minimal. First, Brussaard (2004) found that the abundances of some virus isolates determined for samples frozen at $-80^{\circ} \mathrm{C}$ were, in general, only slightly $(<10 \%)$ lower than those determined for samples flash frozen in liquid nitrogen. Second, the differences in viral abundance data between the 2 cruises for samples collected at the same depth layer (depth $>1000 \mathrm{~m}$ ) from stations located at the same latitudinal position (SX25 versus ST01, SX26 versus ST02, SX27 versus ST03, and SX29 versus ST05; Fig. 1) were nonsystematic and relatively small (the average deviation [absolute value] \pm SE was $12.5 \pm 2.1 \%$ ). It is unlikely that the latitudinal viral distribution pattern that we found in deep water was simply an artifact caused by differences in preservation procedures between the 2 cruises.

\section{Viral turnover time and the potential role of viruses in biogeochemical cycles in the ocean's interior}

The observed viral distribution pattern and the proposed lateral transport mechanism were similar to those of dissolved organic carbon (DOC) in the Pacific (Hansell et al. 2009, Hansell 2013), which is thought to have been formed by the replenishment and transport of semi-refractory and refractory DOC, which has a turnover time of 10 to $1000 \mathrm{yr}$ (Carlson 2002, Hansell et al. 2009, Hansell 2013). For viruses to display a DOC-like distribution pattern, the viral turnover time must be long, on the order of 10 to $100 \mathrm{yr}$, which is the transit timescale of deep water masses from the Southern Ocean to the North Pacific (Stuiver et al. 1983). This long viral turnover time apparently contradicts the results of Parada et al. (2007) that viral turnover times were on the order of 11 to $39 \mathrm{~d}$ in North Atlantic deep waters. Although those estimates were longer than those determined for surface viral populations, they are too short to account for a large-scale transport of viruses across oceanic basins. We propose that some viruses could be preserved for long periods (on the order of 10 to $100 \mathrm{yr}$ ) in the deep ocean. This assertion is partly supported by the following information. First, investigators have suggested that virion structures and infectivity can be maintained for periods of decades to a century for certain viruses in sediments (Suttle 2000, Lawrence et al. 2002). Second, some classes of proteins such as porins (Tanoue et al. 1995) and ribulose-1,5-bisphosphate carboxylase/oxygenase (Orellana \& Hansell 2012) sustain their molecular identities in the deep ocean on decadal to centennial timescales. However, the mechanisms underlying the long-term preservation of biochemically identifiable macromolecules (including viruses) in oceanic environments are poorly understood (Nagata 2008, Orellana \& Hansell 2012). Further studies are needed to investigate in greater detail the variability and control of viral turnover times in deep waters.

Note that prokaryotes can also be transported by deep water circulation, but, unlike viruses, prokaryote abundance distributions did not reflect those of water masses in the Pacific (Yokokawa et al. 2013). This is probably because prokaryote turnover times are shorter (1 to 6 yr in bathypelagic layers, Uchimiya et al. 2013, Yokokawa et al. 2013) than the time scale 
of deep water circulation (decadal to centennial). This difference in turnover times between prokaryotes and viruses may explain the generally high VPR in deep waters, despite the low host abundance and productivity.

The difference in viral abundance between the youngest water mass (the Antarctic Bottom Water, AABW, Orsi et al. 1999) and the oldest water mass (the mid-water of the PDW in the North Pacific) was $6.3 \times 10^{8}$ particles $1^{-1}$. This was equivalent to 0.011 $\mu \mathrm{mol} \mathrm{C} \mathrm{kg}^{-1}$, assuming that each virus contains $1.67 \times$ $10^{-11} \mu \mathrm{mol} C$ (Suttle 2005). For the same transit from the AABW to the PDW, the DOC concentration decreased by approximately $3 \mu \mathrm{mol} \mathrm{C} \mathrm{kg}{ }^{-1}(40 \mu \mathrm{mol}$ $\mathrm{C} \mathrm{kg}^{-1}$ in AABW to $37 \mu \mathrm{mol} \mathrm{C} \mathrm{kg}{ }^{-1}$ in the mid-water of the PDW; Data Management Support for the International Global Ocean Carbon and Repeat Hydrography Program, CLIVAR Repeat Section P16S_ 2005: http://cdiac.ornl.gov/oceans/RepeatSections/ clivar_p16s.html). Thus, net viral removal accounted for $0.4 \%$ of the DOC sink (43 $\mathrm{Tg} \mathrm{C} \mathrm{yr}^{-1}$; Hansell et al. 2009 ) in the Pacific. Assuming a viral C:N:P atomic ratio of $\sim 10: 4.5: 1$ (Hewson et al. 2003) and a stoichiometry of the decomposable dissolved organic matter (DOM) pool of 199:20:1 (Hopkinson \& Vallino 2005), viral removal may contribute 1.7 and $7.5 \%$ of the dissolved organic nitrogen and phosphorus sinks, respectively. Thus, viruses might be a significant component of phosphorus in decomposable DOM that is slowly removed from deep water masses.

\section{CONCLUSIONS}

Our data identified novel features in the distribution of viral abundance in deep oceans. The positive relationship $\left(\mathrm{R}^{2}=0.60\right)$ between prokaryote and viral abundances in the upper layers (200 to $2000 \mathrm{~m}$ ) supported the notion that viral abundance was influenced by host availability. In contrast, in deeper water columns (below $2000 \mathrm{~m}$ ), the distribution of viral abundance was only weakly related to prokaryote abundance. Viral abundance was high in the Antarctic bottom waters and then gradually decreased along the paths of the meridional overturning circulation. The VPR was high in bottom waters in subtropical regions where sinking particle fluxes are generally low. These observations are interpreted as an indication that massive viral transport by deep water circulation affects large-scale distribution patterns of viral abundance and VPR in deep oceans, although other mechanisms (i.e. virus-host interactions and sinking particle-mediated viral transport) may also be involved in shaping viral distribution patterns depending on depth and region. Future studies are required to identify prevailing mode and mechanisms for viral production and decay in deep oceans, which appear to be largely distinct from those in upper oceans.

Acknowledgements. We thank the directors, colleagues, captains, officers, and crews of the RV 'Hakuho-Maru' for support during the cruises. We also thank H. Hasumi for providing useful information on deep water circulation and $\mathrm{S}$. Itoh for assisting in the construction of FddMAP (a database). This study was supported by the Japan Society for the Promotion of Science (JSPS) KAKENHI grants (17201004, 20310010, 24241003) awarded to T.N. T.Y. was supported by the Atmosphere and Ocean Research Institute Cooperative research program.

\section{LITERATURE CITED}

Anderson MJ, Gorley RN, Clarke KR (2008) PERMANOVA+ for PRIMER: guide to software and statistical methods. PRIMER-E, Plymouth

Arístegui J, Gasol JM, Duarte CM, Herndl GJ (2009) Microbial oceanography of the dark ocean's pelagic realm. Limnol Oceanogr 54:1501-1529

Bochdansky AB, van Aken HM, Herndl GJ (2010) Role of macroscopic particles in deep-sea oxygen consumption. Proc Natl Acad Sci USA 107:8287-8291

> Breitbart M (2012) Marine viruses: truth or dare. Annu Rev Mar Sci 4:425-448

$>$ Brussaard CPD (2004) Optimization of procedures for counting viruses by flow cytometry. Appl Environ Microbiol 70:1506-1513

Carlson CA (2002) Production and removal processes. In: Hansell DA, Carlson CA (eds) Biogeochemistry of marine dissolved organic matter. Academic Press, San Diego, CA, p 91-151

> Danovaro R, Corinaldesi C, Dell'Anno A, Fuhrman JA, Middelburg JJ, Noble RT, Suttle CA (2011) Marine viruses and global climate change. FEMS Microbiol Rev 35: 993-1034

> De Corte D, Sintes E, Winter C, Yokokawa T, Reinthaler T, Herndl GJ (2010) Links between viral and prokaryotic communities throughout the water column in the (sub)tropical Atlantic Ocean. ISME J 4:1431-1442

> De Corte D, Sintes E, Yokokawa T, Reinthaler T, Herndl GJ (2012) Links between viruses and prokaryotes throughout the water column along a North Atlantic latitudinal transect. ISME J 6:1566-1577

Fonda Umani S, Malisana E, Focaracci F, Magagnini M, Corinaldesi C, Danovaro R (2010) Disentangling the effect of viruses and nanoflagellates on prokaryotes in bathypelagic waters of the Mediterranean Sea. Mar Ecol Prog Ser 418:73-85

Hansell DA (2013) Recalcitrant dissolved organic carbon fractions. Annu Rev Mar Sci 5:421-445

> Hansell DA, Carlson CA, Repeta DJ, Schlitzer R (2009) Dissolved organic matter in the ocean. Oceanography 22:202-211

Hewson I, Vargo GA, Fuhrman JA (2003) Bacterial diversity in shallow oligotrophic marine benthos and overlying 
waters: effects of virus infection, containment, and nutrient enrichment. Microb Ecol 46:322-336

Honjo S, Manganini SJ, Krishfield RA, Francois R (2008) Particulate organic carbon fluxes to the ocean interior and factors controlling the biological pump: a synthesis of global sediment trap programs since 1983. Prog Oceanogr 76:217-285

Hopkinson CS Jr, Vallino JJ (2005) Efficient export of carbon to the deep ocean through dissolved organic matter. Nature 433:142-145

Hwang CY, Cho BC (2010) Distribution of virus-infected bacteria in the western equatorial Pacific. Pac Sci 64:177-186

Kwon EY, Primeau F, Sarmiento JL (2009) The impact of remineralization depth on the air-sea carbon balance. Nat Geosci 2:630-635

Lawrence JE, Chan AM, Suttle CA (2002) Viruses causing lysis of the toxic bloom-forming alga Heterosigma akashiwo (Raphidophyceae) are widespread in coastal sediments of British Columbia, Canada. Limnol Oceanogr 47:545-550

Longhurst A (2006) Ecological geography of the sea, 2nd edn. Academic Press, San Diego, CA

Matsumoto K (2007) Radiocarbon-based circulation age of the world oceans. J Geophys Res 112, C09004, doi:10. 1029/2007JC004095

Nagata T (2008) Organic matter-bacteria interactions in seawater. In: Kirchman DL (ed) Microbial ecology of the oceans, 2nd edn. John Wiley \& Sons, Hoboken, NJ, p 207-241

Nagata T, Tamburini C, Arístegui J, Baltar F and others (2010) Emerging concepts on microbial processes in the bathypelagic ocean - ecology, biogeochemistry and genomics. Deep-Sea Res II 57:1519-1536

Orellana MV, Hansell DA (2012) Ribulose-1,5-bisphosphate carboxylase/oxygenase (RuBisCO): a long-lived protein in the deep ocean. Limnol Oceanogr 57:826-834

Orsi AH, Johnson GC, Bullister JL (1999) Circulation, mixing, and production of Antarctic Bottom Water. Prog Oceanogr 43:55-109

Parada V, Herndl GJ, Weinbauer MG (2006) Viral burst size of heterotrophic prokaryotes in aquatic systems. J Mar Biol Assoc UK 86:613-621

Parada V, Sintes E, van Aken HM, Weinbauer MG, Herndl GJ (2007) Viral abundance, decay, and diversity in the meso- and bathypelagic waters of the North Atlantic. Appl Environ Microbiol 73:4429-4438

Proctor LM, Fuhrman JA (1991) Roles of viral infection in

Editorial responsibility: Curtis Suttle,

Vancouver, Canada organic particle flux. Mar Ecol Prog Ser 69:133-142

Sarmiento JL, Gruber N (2006) Ocean biogeochemical dynamics. Princeton University Press, Princeton, NJ

Schmitz WJ Jr (1996) On the world ocean circulation, Vol II. The Pacific and Indian Oceans: a global update. Tech Rep WHOI-96-08. Woods Hole Oceanographic Institution, Woods Hole, MA

Stuiver M, Quay PD, Ostlund HG (1983) Abyssal water carbon-14 distribution and the age of the world oceans. Science 219:849-851

Suttle CA (2000) Cyanophages and their role in the ecology of cyanobacteria. In: Whitton BA, Potts M (eds) The ecology of cyanobacteria. Kluwer Academic Publishers, Dordrecht, p 563-589

Suttle CA (2005) Viruses in the sea. Nature 437:356-361

Suttle CA (2007) Marine viruses-major players in the global ecosystem. Nat Rev Microbiol 5:801-812

- Tanoue E, Nishiyama S, Kamo M, Tsugita A (1995) Bacterial membranes: possible source of a major dissolved protein in seawater. Geochim Cosmochim Acta 59:2643-2648

Taylor GT, Hein C, Iabichella M (2003) Temporal variations in viral distributions in the anoxic Cariaco Basin. Aquat Microb Ecol 30:103-116

Uchimiya M, Fukuda H, Nishino S, Kikuchi T, Ogawa H, Nagata T (2013) Vertical distribution of prokaryote production and abundance in the mesopelagic and bathypelagic layers of the Canada Basin, western Arctic: implications for the mode and extent of organic carbon delivery. Deep-Sea Res I 71:103-112

Weinbauer MG, Brettar I, Höfle MG (2003) Lysogeny and virus-induced mortality of bacterioplankton in surface, deep, and anoxic marine waters. Limnol Oceanogr 48: $1457-1465$

Wen K, Ortmann AC, Suttle CA (2004) Accurate estimation of viral abundance by epifluorescence microscopy. Appl Environ Microbiol 70:3862-3867

> Wommack KE, Colwell RR (2000) Virioplankton: viruses in aquatic ecosystems. Microbiol Mol Biol Rev 64: 69-114

> Yang Y, Motegi C, Yokokawa T, Nagata T (2010) Largescale distribution patterns of virioplankton in the upper ocean. Aquat Microb Ecol 60:233-246

Yokokawa T, Yang Y, Motegi C, Nagata T (2013) Largescale geographical variation in prokaryotic abundances and production in meso- and bathypelagic zones of the central Pacific and the Southern Ocean. Limnol Oceanogr 58:61-73

Submitted: April 10, 2013; Accepted: October 23, 2013 Proofs received from author(s): January 7, 2014 